\title{
Er det «perfekte» mennesket målet?
}

\author{
Grensen for selvbestemt abort er \\ uke 12. Senere må det søkes, unn- \\ tatt når fosteret har Downs syn- \\ drom eller en annen funksjons- \\ hemning som regnes som alvorlig. \\ Da blir det et tilbud. Kan dette \\ regnes som lovbrudd? Er det noen \\ fostre som ikke har samme \\ beskyttelse som andre?
}

Medisinskfaglig råd har gått inn for at alle gravide skal få tilbud om tidlig ultralyd i uke 12 av svangerskapet, til tross for at Nasjonalt kunnskapssenter for helsetjenesten har gitt melding om at dette ikke innebærer noen helsegevinst. «Gevinsten» man kan få, er hovedsakelig mistanken om at fosteret har Downs syndrom. En slik mistanke vil føre til flere prøver, bl.a. fostervannsprøve, som innebærer risiko for spontanabort. Dersom mistanken blir bekreftet, vil tilbudet om «behandling» være abort, så sent som i uke $20.90 \%$ av dem som får påvist mistanke om Downs syndrom tar abort.

Jeg er selv en kvinne med Downs syndrom. Jeg er ikke syk, jeg har ikke en kromosomfeil - jeg har ett ekstra kromosom i mine celler. Er jeg ikke ønsket? Er jeg ikke «vellykket» nok til å ha livets rett?

Dersom denne loven blir vedtatt, kan det føles enda mer usikkert å få et barn med Downs syndrom. I Danmark, hvor tidlig ultralyd er innført for flere år siden, bygges nå støtten til familier som trenger hjelp ned. De løste jo ikke «problemet» ved å abortere fosteret, slik de fikk tilbud om.

Dette er i tråd med Danmarks nasjonale mål. Innen år 2030 skal det ikke fødes barn med Downs syndrom. Disse skal være utryddet innen den tid.

I 1991 kom det en høringsuttalelse fra legehold her til lands: «Det ville være en stor fordel om tilstander som Downs syndrom kunne utryddes helt.» Slikt sier man ikke høyt i dag, men i stedet kan dette ønsket nå være i ferd med å bli realisert. Vi er utrydningstruet!

Onsdag 26.1. 2011 fremmet Arbeiderpartiet forslag om tidlig ultralyd til alle gravide i uke 12. Dette ville være en helsegevinst, hevdet man, noe som er grundig tilbakevist. Informasjonen var basert på et tett samarbeid mellom Nasjonalt senter for fostermedisin i Trondheim ved professor Sturla Eik-Nes, professor Kjell Åsmund Salvesen og Arbeiderpartiet.

Hvorfor hører ikke Ap-politikerne også på kritiske røster og vitenskapelig dokumentasjon som taler imot den såkalte helsegevinsten? Samtidig uttaler både AnneGrete Strøm-Erichsen og Jens Stoltenberg at de ønsker et samfunn med plass til alle. Min påstand: De lyver!

Igjen - passer vi ikke inn i et «vellykket, perfekt samfunn»? Koster vi for mye?

Så til Nasjonalt senter for fostermedisin i Trondheim. De ønsker å starte et forskningsprosjekt med ultralydunders $\emptyset$ kelse til gravide i uke 12. Hvorfor informerer Sturla Eik-Nes og Kjell Åsmund Salvesen Ap-politikere om stor helsegevinst - når det er dokumentert at dette ikke er tilfellet?

Hvorfor påstår fostermedisiner Kjell Åsmund Salvesen dette: «Vi ønsker å gjøre noe bra for fosteret, ikke å finne flest mulige Downs syndrom.» Er det «bra for fosteret» at hovedresultatet blir senaborter for $90 \%$ av fostre med Downs syndrom, pluss noen spontanaborter i forbindelse med fostervannsprøve? De lyver! Bioteknologilovens formålsparagraf: «Formålet med denne loven er å sikre at medisinsk bruk av bioteknologi utnyttes til beste for mennesker $\mathrm{i}$ et samfunn der det er plass til alle. Dette skal skje i samsvar med prinsipper om respekt for menneskeverd, menneskelige rettigheter og personlig integritet og uten diskriminering på grunnlag av arveanlegg basert på etiske normer nedfelt i vår vestlige kulturarv.»

I vår vestlige kulturarv har det ikke vært plass til mennesker med Downs syndrom, og er det tydeligvis ikke ennå. Vi er blitt gjemt bort på store institusjoner så folk skulle slippe å se oss. Botilbudet er fremdeles institusjon. På skolen blir vi plassert i spesialgrupper. Vi har ikke rett til utdanning utover videregående skole, og det forventes at vi uføretrygdes. Er man heldig, kan man få plass på en varig tilrettelagt arbeidsplass med noen få kroner timen i lønn.

Nå foreslår Arbeiderpartiet en lov som resulterer i at vi blir tatt livet av før vi bli født. Vi er ikke ønsket i landet!

Fostermedisinernes aktivitet begrenses i dag av formålsparagrafen i bioteknologiloven. Blir denne fjernet, får forskerne mer forskningsmateriale til sin egen forskning, noe som kan ses som ønskelig for fostermedisinerne. Men til hvilken pris? Sakens kjerne er ikke for eller imot abort, men om vi ønsker et sorteringssamfunn hvor vi kan dyrke frem det såkalt perfekte mennesket. Teknologien er rett rundt hjørnet. Tidlig ultralyd er bare begynnelsen.

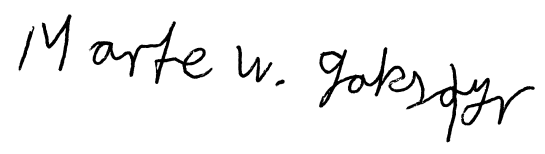

